\title{
Maintaining hepatocyte differentiation in vitro through co-culture with hepatic stellate cells
}

\author{
Petra Krause • Farahnaz Saghatolislam • Sarah Koenig • \\ Kirsten Unthan-Fechner • Irmelin Probst
}

Received: 19 August 2008 / Accepted: 10 December 2008 / Published online: 28 January 2009 / Editor: J. Denry Sato

(C) The Author(s) 2009. This article is published with open access at Springerlink.com

\begin{abstract}
Primary hepatocytes lose their differentiated functions rapidly when in culture. Our aim was to maintain the differentiated status of hepatocytes in vitro by means of vital hepatic stellate cells (HSCs), their soluble and particulate factors and lipid extracts. Hepatocytes were placed into collagen-coated culture dishes in the presence of HSCs at different ages of pre-culture, with or without direct cell to cell contacts, at different cell ratios and in monoculture with cellular HSC components in place of vital cells. Changes in morphology and enhancement of phosphoenolpyruvate carboxykinase (PCK) activity by glucagon were used to determine the differentiated status of hepatocytes in 2d-short-term culture. HSCs proved able to maintain the differentiated function of hepatocytes in coculture either by direct cell contacts or via factors derived from HSC-conditioned medium. In comparison, however, without cellular contact to hepatocytes five to ten times as many HSCs were necessary to increase the PCK activity to the same degree as in the presence of intercellular contacts. Whereas stimulation in the presence of HSC/hepatocyte contacts was independent of HSC culture age only quiescent, resting HSCs (precultured for 1-2 d) were able to stimulate hepatocytes significantly via soluble factors. Culturing of hepatocytes with a lipid extract or a particulate fraction from
\end{abstract}

F. Saghatolislam $\cdot$ K. Unthan-Fechner $\cdot$ I. Probst $(\bowtie)$

Department of Biochemistry I,

Centre of Biochemistry and Molecular Cell Biology,

Georg-August University Goettingen,

Humboldtallee 23,

37073 Goettingen, Germany

e-mail: iprobst@gwdg.de

P. Krause $\cdot$ S. Koenig

Department of General Surgery,

Georg-August University Goettingen,

Goettingen, Germany
HSCs clearly displayed a very strong beneficial effect on enzyme activity and morphology. HSCs maintain hepatocyte function and structure through preferentially cell-bound signalling and transfer of lipids.

Keywords Hepatic stellate cells · Hepatocytes .

Differentiation - Phosphoenolpyruvate carboxykinase .

Co-culture

\section{Introduction}

When in cell culture, primary hepatocytes are known to lose their differentiated phenotype and vitality rapidly on isolation from their native microenvironment (Arterburn et al. 1995; Runge et al. 2000). Therefore, many investigators have been developing sophisticated cell culture systems aiming to maintain the vitality and specific metabolic functions (Elaut et al. 2006). Elaborate culture media and/ or the use of complex extracellular matrices (ECM) help to prevent the metabolic deterioration and re-establish hepatic polarity in primary hepatocyte cultures (Enat et al. 1984; Block et al. 1996; Mitaka 1998). More precisely, not only do the culture medium and cell dish surface play a pivotal role in the maintenance of hepatocytes in vitro, heterotypic cell to cell interactions are also imperative to maintain coordinated cell functions in vitro. Initial attempts were made by preserving the morphology and biochemical integrity of hepatocytes in co-culture with extrahepatic cells (e.g. fibroblasts, endothelial cells) (Langenbach et al. 1979; Talamini et al. 1998). However, the co-culture of mature hepatocytes with non-parenchymal (stromal) cells from the liver itself has been shown to be more effective in modulating cell differentiation (Bader et al. 1996; Bhatia et al. 1999; Ries et al. 2000). Various two and three 
dimensional co-culture models have demonstrated their ability to mimic the liver microenvironment, suggesting that each hepatic non-parenchymal cell population (sinusoidal endothelium, Kupffer cells and hepatic stellate cells (HSCs)) may contribute to the overall beneficial effect on hepatocytes (Morin and Normand 1986; Okamoto et al. 1998; Riccalton-Banks et al. 2003; Thomas et al. 2005; Zinchenko et al. 2006a).

To date, only few studies have focussed on co-culturing hepatocytes with individual non-parenchymal cell fractions. In particular, the exact role of HSCs needs to be elucidated further with respect to their culture age and to signals generated by membrane contact or by cytoplasmic/soluble factors. HSCs constitute a mesenchymal cell type and display unique features with respect to their cellular origin, morphology and function (Suematsu and Aiso 2001). Normal, quiescent HSCs store over $80 \%$ of total body vitamin A and maintain vitamin A blood homoeostasis (Sato et al. 2003). HSCs are located between parenchymal cell plates and sinusoidal endothelial cells and extend welldeveloped, long processes surrounding sinusoids in vivo as pericytes (Senoo 2004). They are the predominant cell type producing ECM components as well as ECM-degrading metalloproteases, indicating that they play a pivotal role in ECM remodelling in both normal and pathological liver conditions (Kmiec 2001).

The central question of our study was as to whether primary, quiescent HSCs maintain the phenotype and gluconeogenic activity of hepatocytes either in a co-culture setting with direct cell to cell contacts, via soluble factors in the culture medium and/or via cellular components such as particulate cell material and lipids.

\section{Materials and Methods}

Animals and Reagents. Male Wistar rats were purchased from Winkelmann (Borchen, Germany) and kept on a $12 \mathrm{~h}$ day/night rhythm with a standard rat diet. Collagenase, epidermal growth factor, basic fibroblast growth factor, as well as neonatal calf serum were purchased from Biochrom (Berlin, Germany). Williams Medium E with $5 \mathrm{mM}$ glucose and holo-transferrin were supplied by Applichem (Darmstadt, Germany). Bovine insulin was purchased from Serva (Heidelberg, Germany), inosine triphosphate from Aldrich (Taufkirchen, Germany), pronase from Merck (Darmstadt, Germany), Nycodenz from Nycomed Pharma (Oslo, Norway) and Percoll from Pharmacia (Freiburg, Germany). All further chemicals were supplied by Sigma (Deisenhofen, Germany).

Isolation of hepatocytes and non-parenchymal (stromal) cells. Hepatocytes were isolated from 250-300 g rats using the collagenase perfusion protocol exactly as described (Ries et al. 2000). Hepatocytes were re-suspended in Williams E medium with $5 \mathrm{mM}$ glucose containing $4 \%$ NCS, $0.2 \%$ bovine serum albumin, $15 \mathrm{mM}$ HEPES, $0.2 \mathrm{mM}$ ethanolamine, $0.2 \mathrm{mM}$ phosphoethanolamine, $7.5 \mathrm{nM}$ sodium selenite, $0.1 \mu \mathrm{M}$ dexamethasone and $1 \mathrm{nM}$ insulin. Hepatocytes were plated onto $60-\mathrm{mm}$ dishes which were pre-coated with rat tail collagen (not crosslinked) and dried for $24 \mathrm{~h}$. After $4 \mathrm{~h}$, the medium was changed to the medium mentioned above; serum was omitted from now on. Thereafter, medium was changed daily $(2.5 \mathrm{ml} / \mathrm{dish})$. The supernatant of the first centrifugation contained the non-parenchymal cells (NPCs) as a mixture of endothelial, HSCs and Kupffer cells. These cells were washed twice in Williams medium (sedimentation at $200 \mathrm{~g}$ for $10 \mathrm{~min}$ ) and re-suspended in $5 \mathrm{ml}$ medium, of which $150 \mu \mathrm{l} / \mathrm{dish}$ were plated together with the hepatocytes (Ries et al. 2000).

Isolation and culture of stellate cells. Cells were isolated using a combined two-step pronase/collagenase digestion (Weiner et al. 1992; Pestel et al. 2003). Briefly, the liver from $350-450 \mathrm{~g}$ rats was excised during pre-perfusion with Hanks balanced salt solution (HBSS) without $\mathrm{Mg}^{2+}$ and $\mathrm{Ca}^{2+}$ at a flow rate of $7.5 \mathrm{ml} / \mathrm{min}$. Flow rate was then increased to $20 \mathrm{ml} / \mathrm{min}$ and perfusions continued ex situ: first with $100 \mathrm{ml}$ HBSS and $0.035 \%$ pronase in a nonrecirculating manner and then with $100 \mathrm{ml}$ HBSS plus $0.028 \%$ collagenase for $20-30 \mathrm{~min}$ under recirculation. The soft liver was mechanically dispersed and the crude tissue aggregates slowly stirred in $100 \mathrm{ml}$ HBSS with $100 \mathrm{mg}$ pronase, $2 \mathrm{mg}$ DNase and $25 \mathrm{mg}$ BSA for $10 \mathrm{~min}$ under constant readjustment of the $\mathrm{pH}$ to 7.4. Cells were filtered through a $60 \mu \mathrm{m}$ nylon mesh, freed of hepatocytes by centrifugation ( $50 \mathrm{~g}$ for $7 \mathrm{~min}$ ), pelleted (450 $\mathrm{g}$ for $7 \mathrm{~min}$ ), re-suspended in HBSS plus DNase and mixed with Nycodenz to a final concentration of $8.1 \%$ in a total volume of $160 \mathrm{ml}$. Aliquots of $20 \mathrm{ml}$ were overlaid with $8 \mathrm{ml} \mathrm{HBSS}$ in $30 \mathrm{ml}$ Corex tubes and centrifuged for $20 \mathrm{~min}$ at $1,400 \mathrm{~g}$. HSC were obtained from the interphase, washed once, re-suspended in Williams medium with $15 \%$ foetal calf serum, $0.1 \mu \mathrm{M}$ dexamethasone, $1 \mathrm{nM}$ insulin and plated into $60-\mathrm{mm}$ dishes coated with native (not crosslinked) collagen for short-term cultures (24-48 h), or with glutaraldehyde-crosslinked collagen for long-term cultures $(>2$ d). For short-term cultures, foetal calf serum was omitted after the first medium change $(3 \mathrm{~h})$ and long-term cultures were freed of serum $24 \mathrm{~h}$ before the experiments. HSCs were identified by their characteristic lipid droplet inclusion (light microscopy, autofluorescence) and positive vimentin staining. Purity was determined as being $>90 \%$, vitality $80 \%$ and the yield was $30-40$ million cells/liver. Kupffer cells were not detected (phagocytosis of fluorescent 
latex beads, ED2 antibody staining). Occasionally, sinusoidal endothelial cells $(<5 \%$, detection by the uptake of fluorescent acetylated LDL) adhered to the dish, but these cells were detached after $20 \mathrm{~h}$ of culture.

HSC conditioned medium. HSC $\left(4 \times 10^{6}\right)$ were cultured as described above on dishes coated with glutaraldehydecrosslinked collagen. Conditioned media were sampled between $24-48 \mathrm{~h}$ of the culture and for long-term cultures in the last serum-free 24 -h period. They were sterilised by filtration, centrifuged at $10,000 \times \mathrm{g}$ for $30 \mathrm{~min}$ and used without storing longer than $24 \mathrm{~h}$ at $4^{\circ} \mathrm{C}$. Cells received $50 \%$ $\mathrm{CM}$ (as a 1:1 mixture with hepatocyte culture medium) at the 4 and $24 \mathrm{~h}$ changes.

Preparation of HSC particulate fraction. HSC were precultured for 2 or 7-21 d, washed twice with Williams medium, scraped off the dish and were sonicated in $500 \mu \mathrm{l}$ medium for $20 \mathrm{~s}$ at a low frequency. The particulate fraction was pelleted (14,000 rpm, $20 \mathrm{~min})$, washed once and was re-suspended in medium with $10 \mathrm{nM}$ insulin and $0.1 \mu \mathrm{M}$ dexamethasone. Hepatocytes were supplied with $1.5 \mathrm{ml}$ culture medium and $500 \mu \mathrm{l}$ particulate fraction (from $2 \times$ $10^{6} \mathrm{HSC} /$ dish) at the first medium change.

Lipid extraction. Four dishes each of $3 \times 10^{6} \mathrm{HSCs}$ or hepatocytes were cultured for $24 \mathrm{~h}$ and used for extraction exactly as described previously (Probst et al. 2003). The chloroform phase was transferred into a sterile $50-\mathrm{ml}$ glass medium flask and the solvent was evaporated under $\mathrm{N}_{2}$ in the dark. Lipids were re-dissolved in $24 \mathrm{ml}$ of Williams medium containing $0.1 \mu \mathrm{M}$ dexamethasone and $1 \mathrm{nM}$ insulin by stirring at $4^{\circ} \mathrm{C}$ for $6 \mathrm{~h}$. Lipids were used immediately at a 1:2 dilution with culture medium (lipids of $1 \times 10^{6}$ cells $/$ dish).

Experimental design of cell cultures. Hepatocyte seeding density was 0.5 or $1 \times 10^{6}$ cells/dish. For co-culturing purposes, HSCs were pre-cultured for various lengths of time, hepatocytes were then seeded onto the HSC dish and cultured for $2 \mathrm{~d}$ before the induction of phosphoenolpyruvate carboxykinase (PCK) by glucagon. Ring cultures were used to separate the two cell types physically on one dish (Schrode et al. 1990); a 4-mm plastic ring was cut off a $50-\mathrm{ml}$ Falcon tube, sterilised and glued into the centre of the $60-\mathrm{mm}$ dish using collagen. Hepatocytes were always seeded into the outer ring. HSCs were seeded at different densities either into the outer ring (cell contact with hepatocytes) or into the inner circle (no cell contact). The ring was removed during the first medium change $(4 \mathrm{~h})$.

Determination of phosphoenolpyruvate carboxykinase activity. Cell cultures were washed twice and incubated with
Williams E-based culture medium without serum and insulin but containing $0.1 \mu \mathrm{M}$ dexamethasone and $2 \mathrm{mM}$ lactate. After $30 \mathrm{~min}$, the experiment was initiated by adding $10 \mathrm{nM}$ glucagon. The incubation was terminated after $6 \mathrm{~h}$ by rinsing the plates once with $0.9 \%$ saline solution and subjecting the dishes to liquid nitrogen. Enzyme activity was determined photometrically (Seubert and Huth 1965).

Miscellaneous. The dissolution of rat tail collagen and its crosslinking with glutaraldehyde were done as described (Ries et al. 2000). Dishes were coated with either native or crosslinked collagen and allowed to dry for $24 \mathrm{~h}$. Cell morphology was assessed by phase contrast light microscopy (LEICA DM IRE2, Bensheim, Germany).

\section{Results}

In different co-culture settings, we investigated the induction of PCK activity following glucagon stimulation. This complex function represents a gluconeogenic key function of metabolically active hepatocytes and can therefore be considered as a major phenotypic differentiation marker (Iynedjian et al. 1995; Ries et al. 2000). We specifically chose a culture system, in which hepatocytes were seeded at low density and in a standard medium leading to a more rapid loss of differentiated function in monoculture. This approach helped in revealing early differences within $2 \mathrm{~d}$ of hepatocytes being exposed to various culture settings. In pure hepatocyte cultures, baseline PCK activity was very low $(0.2 \pm 0.03 \mathrm{U} / \mathrm{mg}$ DNA) and could be stimulated 5.8fold following glucagon application (Fig. 1). This glucagon-stimulated value was set as the reference value of 1 relative unit. Glucagon-dependent activity was significantly increased further by an approximate factor of 2 when hepatocytes were co-cultured with HSCs, regardless of HSC culture age. Co-culture did not increase the basal unstimulated PCK activity (data not shown).

Owing to the low-plating density used for this study, changes in cell morphology could already be observed within $2 \mathrm{~d}$. Once attached to the cell culture dish surface, hepatocytes changed within $48 \mathrm{~h}$ from single polygonal cells to near confluent clusters of extended, flattened monolayer cells with levelled nuclei (Fig. 2a). The hepatocyte cytoplasm displayed large numbers of granules and only very occasionally could the formation of bile canaliculi be observed. When hepatocytes were cultured in the presence of HSCs pre-cultured for $24 \mathrm{~h}$, the loss of differentiated phenotype was attenuated. Compact clusters were visible and star-like bile canaliculi were formed by the apical membranes of adjacent hepatocytes, demonstrating 


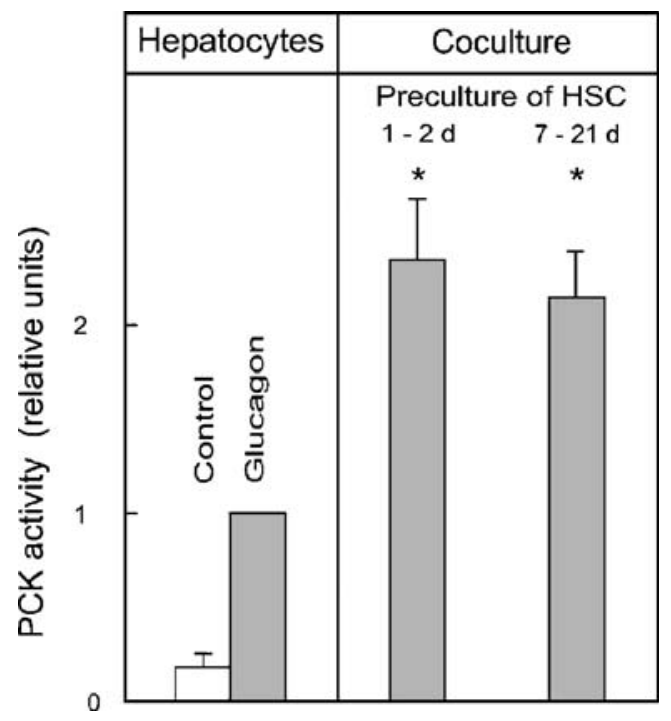

Figure 1. Improved glucagon stimulated increase of phosphoenolpyruvate carboxykinase (PCK) activity in hepatocytes cultured with hepatic stellate cells (HSCs). HSCs $\left(2 \times 10^{6}\right)$ were pre-cultured either for $1-2$ or $7-21 \mathrm{~d}$ before the start of the $2 \mathrm{~d}$ co-culture with $5 \times 10^{5}$ hepatocytes. Activities (mU/dish) are expressed as relative units with the value for the glucagon-treated pure hepatocyte culture set to $1 \mathrm{U}$. Data are mean $\pm \mathrm{SD}$ from five different hepatocyte and ten different HSC preparations. $* p<0.05$ versus glucagons-treated pure hepatocytes.

their membrane polarity (Fig. 2b). HSCs contained the characteristic fat droplets and developed elongated cytoplasmatic extensions, which linked the clusters of the hepatocytes. When HSCs were pre-cultured for $7 \mathrm{~d}$, they had spread to confluence. The fat droplets of these levelled HSC could no longer be detected as part of the dedifferentiation process. However, the morphology of hepatocytes piling on HSCs was grossly maintained, as seen by their polygonal cell shape, high contrast margins and reestablishment of bile canaliculi (data not shown).

As co-cultured HSCs proved to have a beneficial effect on both the function and morphology of hepatocytes, the need for intercellular contacts between hepatocytes and HSCs was evaluated at different cell ratios (Fig. 3). In a ring culture system, a constant number of hepatocytes $\left(5.0 \times 10^{5}\right)$ was seeded into the outer ring, whereas HSCs were placed at different densities $(0.1,0.2,0.5$ and $2.0 \times$ $10^{6}$ ) either into the outer ring enabling direct cell to cell contact, or into the inner circle. The ring was removed after $4 \mathrm{~h}$ of plating, therefore allowing the soluble factors to spread throughout the dish. Light and scanning electron microscopy excluded any migration of HSCs into the hepatocyte compartment when plated separately (data not shown). As published previously (Ries et al. 2000), cocultured NPCs (a mixture of sinusoidal endothelial cells, HSCs and Kupffer cells) with cell contact to hepatocytes significantly improved the glucagon-dependent increase of PCK activity in hepatocytes (a 12.9-fold increase for NPC co-cultures versus a 3.7-fold increase for pure cultures). In co-cultures allowing for cell contacts, the ratio of hepatocytes to HSCs of 1:4 proved to be as efficient in enhancing the hormone responsiveness (factor of 12.4) as the coculture with NPCs. Ever decreasing values were measured with increasing ratios of 1:1 (factor of 10.7), 2.5:1 (9.6) and $5: 1$ (5.2). In co-cultures without cell contacts, a significant further enhancement of the glucagon effect (maximum increase 8.5 -fold) was observed only when HSCs equalled or outnumbered the hepatocytes. To summarise, the HSCs exerted a favourable effect on the differentiated function of
Figure 2. Morphology of $2 \mathrm{~d}$ hepatocyte cultures. Light microscopy of $5 \times 10^{5}$ hepatocytes in pure culture $(a)$ and in coculture with $1 \times 10^{6}$ HSCs being pre-cultured for $24 \mathrm{~h}(b)$, hepatocytes cultured with sonicated HSC membranes $(c)$ and with HSC lipid extracts $(d)$.
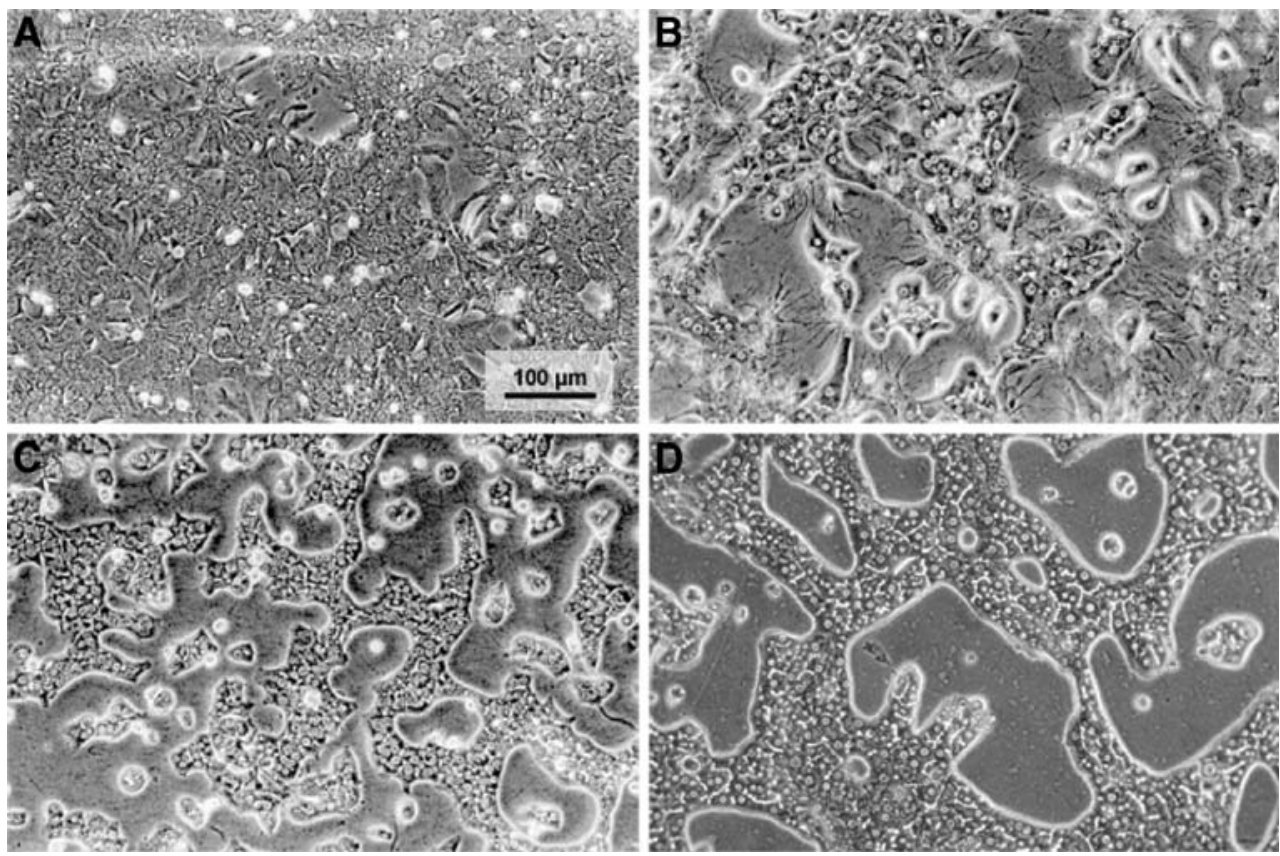


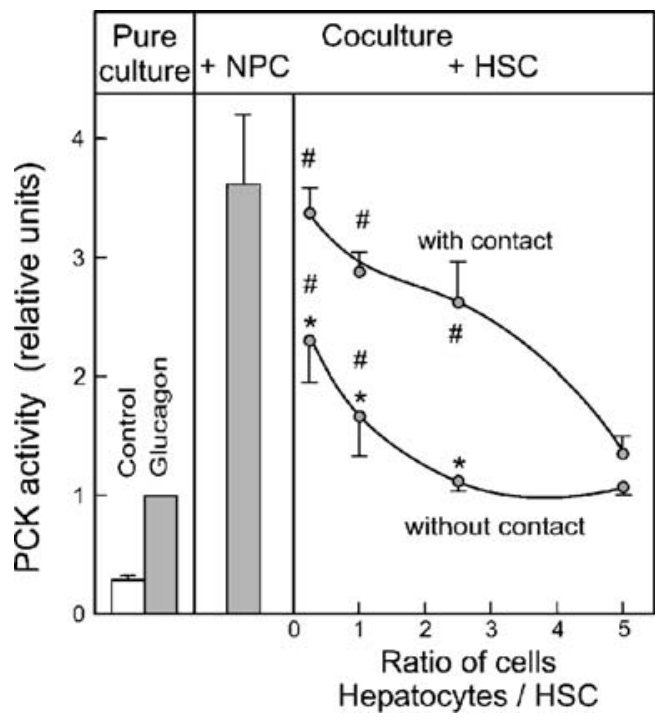

Figure 3. Glucagon-dependent increase of PCK activities in hepatocytes with and without contact with HSCs plated at different densities. HSCs were pre-cultured at different cell numbers $(0.1,0.2,0.5,2 \times$ $10^{6}$ ) either in the outer (cell contact) or inner (no contact) area of the ring culture; $5 \times 10^{5}$ hepatocytes were seeded into the outer ring, which was then removed for the $2 \mathrm{~d}$ co-culture. NPCs were plated together with hepatocytes. All co-cultures were treated with glucagon. Data are mean \pm SEM from five different cell preparations. $* p<0.05$ significant difference between co-cultures with or without contact, ${ }^{\#} p<0.05$, significant difference versus glucagon-stimulated pure culture.

hepatocytes in co-culture either by direct cell contacts or via soluble factors derived from the HSCs. However, four times as many HSCs were necessary to stimulate the PCK activity of hepatocytes markedly when compared to cocultures with cell contacts.

In a further experiment, the stimulatory effect of a particulate cell fraction in place of vital HSCs was assessed (Fig. 4). Particulate matter from short-term pre-cultured HSCs (2 d) and from older HSCs (7 to 21 d) significantly increased the glucagon-dependent PCK activity from 5.5fold to 12.7 -fold and 14.7-fold, respectively.

In order to evaluate whether co-cultured hepatocytes may benefit from soluble factors of HSCs, hepatocytes in pure culture were cultured with HSC-conditioned media harvested from HSC pre-cultured for either $2 \mathrm{~d}$ or 7 to $21 \mathrm{~d}$ (Fig. 5). Only quiescent young HSCs produced conditioned medium capable of a significant further enhancement of PCK activity (from 6.2-fold to 24.6-fold over the unstimulated control); when considering older HSC cultures, it appears that intercellular contacts are crucial (see Fig. 4). However, conditioned medium did not maintain hepatocyte structure and polarity (photos not shown).

The effect of lipids extracted from HSCs following $24 \mathrm{~h}$ of culture was tested (Fig. 6). Culture in the presence of HSC lipids increased glucagon-dependent activity from 3.4-fold (no lipids) to sixfold. In contrast, lipids from hepatocytes were not effective. In additional experiments, we supplemented the culture medium with retinol or retinoic acid $(1-10 \mu \mathrm{M})$. There was no detectable effect, contrary to the published data (Falasca et al. 1998).

The beneficial stimulatory effects of a HSC particulate fraction and of the HSC lipid extract on PCK activity were paralleled by maintenance of hepatocyte morphology (Fig. $2 c, d$ ). Hepatocytes clearly revealed compact and in part confluent clusters of high contrast cells. The cell nuclei and margins were easily detected, as well as many surrounding bile canaliculi.

\section{Discussion}

Over the last $30 \mathrm{yr}$, a multitude of studies have demonstrated the maintenance of differentiation when hepatocytes were cultured with a variety of hepatic, non-hepatic epithelial or mesenchymal cells (for a review see Bhatia et al. 1999). Cell associated as well as soluble factors ( $\mathrm{Lu}$ et al. 2005; Zinchenko et al. 2006a, b) were shown to keep the hepatocyte morphologically and functionally differentiated. The hepatocyte is in intricate contact with spiny extensions of the hepatic stellate cell, its nearest cell neighbour. Here, we demonstrate for the first time that primary isolated quiescent HSCs of a young culture age ( 1 to $2 \mathrm{~d}$ ) maintain hepatocyte function and structure through cell contact and soluble factors. Our simple co-culture model allowed us to differentiate between these signals and to estimate soluble and cell-bound signal potency by varying the ratio of

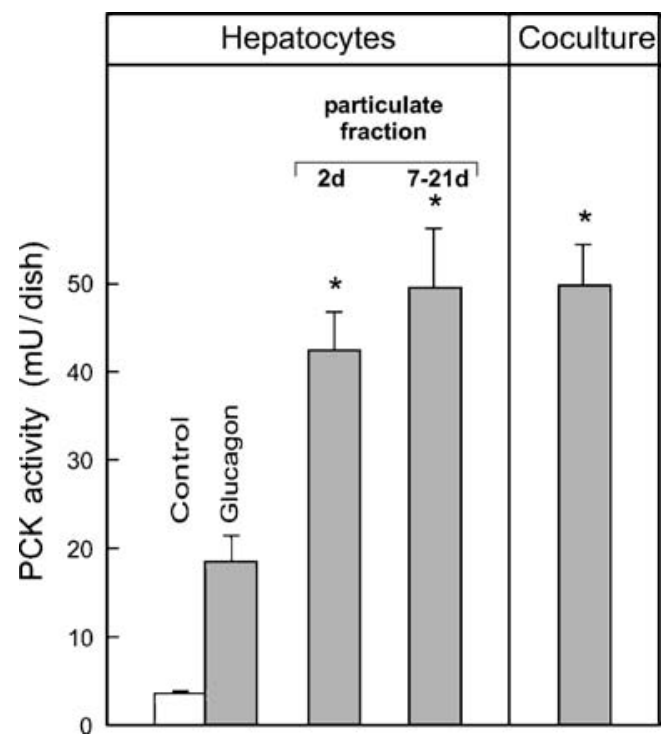

Figure 4. Improved hepatocyte differentiation cultured with HSC particulate fractions. HSC were pre-cultured for 2 or $7-21 \mathrm{~d}$; they were sonicated and a washed particulate fraction was added to the pure hepatocyte cultures $\left(5 \times 10^{5}\right.$ cells $)$ at the first medium change. The co-culture contained $1 \times 10^{6}$ viable HSCs. Data are mean \pm SEM from four different cell preparations. $* p<0.05$, versus glucagon-stimulated pure culture without particulate fraction. 


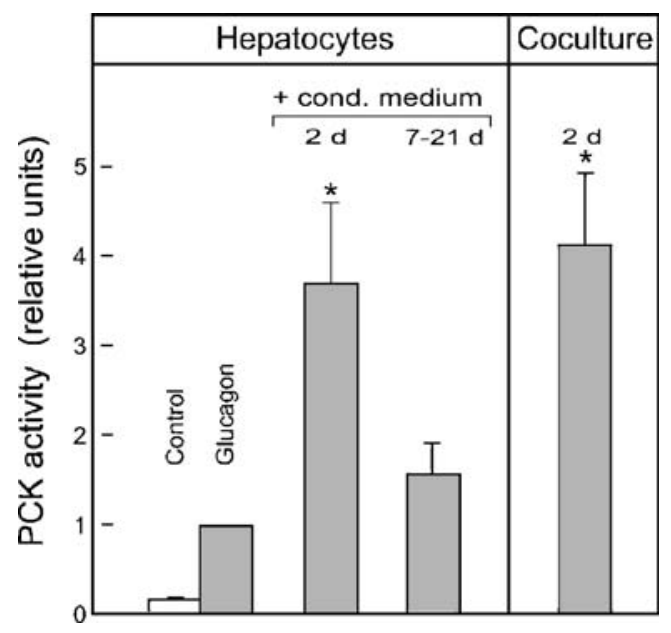

Figure 5. Improved glucagon-stimulated PCK activity in pure hepatocytes in the presence of conditioned medium from HSC precultured for 2 or $7-21 \mathrm{~d}$. Data are mean \pm SEM from four different cell preparations. $* p<0.05$, versus glucagon-stimulated hepatocytes without conditioned medium.

hepatocytes to HSCs on the dish (Fig. 3). Both soluble and membrane-bound signal transfer were only detectable when HSCs outnumbered hepatocytes. Bound signals were superior or exclusive when HSC numbers dropped below the number of hepatocytes. This mirrors the cell architecture in vivo, in which one HSC roughly spans two to three hepatocytes (Sato et al. 2003). Soluble factors provided by HSC medium, conditioned in the absence of hepatocytes, were effective only when the HSCs were still of a young culture age and thus in a differentiated, quiescent state (Fig. 5). Cell-associated signals maintained both function and structure irrespective of HSC culture age and vitality, since washed HSC particulate material acted as substitute for the intact living HSCs (Fig. 4). One explanation for this effect may be the presentation of cadherins, providing for homoadhesive cell to cell contacts. HSCs switch cadherin expression from the E- to N-type during in vivo and in vitro activation (Lim et al. 2007) and both E- and N-cadherins as well as the truncated T-type have been identified as potent mediators of hepatocyte differentiation (Khetani et al. 2004, 2008).

HSCs express another surface-associated molecule, epimorphin, which induces in vitro differentiation of hepatocytes (Watanabe et al. 1998) and hepatic stem-like cells (Miura et al. 2003). The protein is known to act as a morphogen during tissue restoration in the adult liver (Yoshino et al. 2006).

Hepatocytes as well as hepatoma cells preserve/regain functionality and structure when cultured with vitamin A (Falasca et al. 1999; Alisi et al. 2003; Bertagnolo et al. 2003). The commercial culture medium used here contains approximately $0.3 \mu \mathrm{M}$ vitamin A. Any further addition of vitamin $\mathrm{A}$ in different stereoforms of retinol or retinoic acid (dissolved in ethanol or dimethylsulfoxide or alternatively bound to albumin) did not enhance differentiation in our pure hepatocyte cultures (results not shown). However, lipids from HSCs cultured for $1 \mathrm{~d}$, extracted with chloroform and bound to albumin, not only maintained hepatocyte function but also preserved cell architecture and polarity very well with the expression of multiple bile canaliculi (Fig. 2d). Nonetheless, it should well be considered that the active component in the lipid extract was not vitamin A alone, since the lipid droplets of HSCs also contain triglycerides, cholesterol and phospholipids (Yamada et al. 1987; Moriwaki et al. 1988). The antiproliferative and differentiative action of vitamin $\mathrm{A}$ has been well investigated (Fields et al. 2007); more recently unsaturated fatty acids have been recognised as important signals in diverse processes such as differentiation, development and proliferation (Tontonoz and Spiegelman 2008; Edwards and O'Flaherty 2008). The question remains as to how lipids and especially vitamin A from the intracellular HSC stores reach the neighbouring hepatocytes. Sauvant et al. used primary cultures of HSCs (Sauvant et al. 2001), demonstrating that retinol mobilisation did not require the synthesis of and binding to retinol-binding protein (Kawaguchi et al. 2007). Instead, their data support the idea of direct retinol transfer from the HSCs to hepatocytes by the movement of free retinol in phospholipid bilayer membranes with an increased transfer when direct cell contacts between the two cell types were established.

In conclusion, we show that quiescent HSCs maintain hepatocyte function and structure by multiple signals, preferentially cell bound. The results point to non-soluble membraneous ligand contacts as well as to the direct

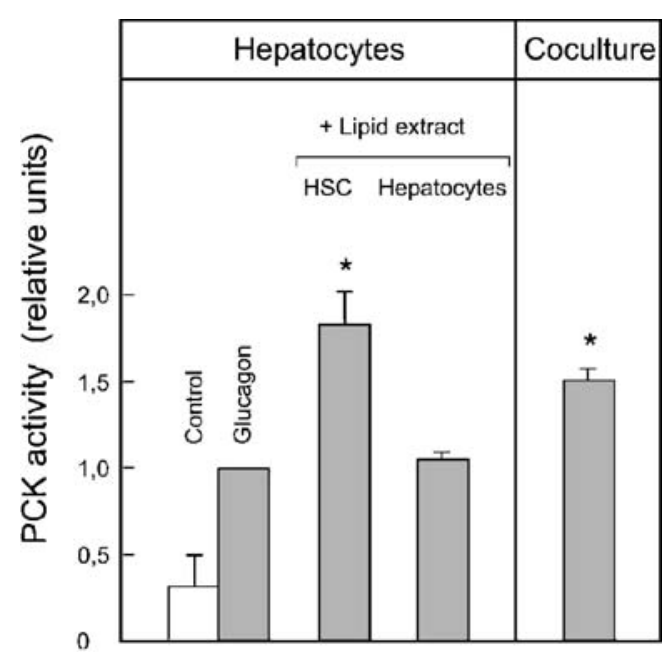

Figure 6. Maintenance of hepatocyte differentiation by HSC lipids. Lipids from HSCs and hepatocytes were added to $1 \times 10^{6}$ hepatocytes at the 4 and $24 \mathrm{~h}$ medium changes. The co-culture contained $1 \times 10^{6}$ viable HSCs. Data are mean \pm SEM from four different cell preparations. $* p<0.05$ versus glucagon-stimulated hepatocytes without lipids. 
intercellular transfer of lipids as key factors in the maintenance of hepatocyte differentiation.

Acknowledgment The authors would like to express their thanks to Andrew Entwistle for his critical review of this manuscript.

Open Access This article is distributed under the terms of the Creative Commons Attribution Noncommercial License which permits any noncommercial use, distribution, and reproduction in any medium, provided the original author(s) and source are credited.

\section{References}

Alisi, A.; Leoni, S.; Piacentani, A.; Conti Devirgiliis, L. Retinoic acid modulates the cell-cycle in fetal rat hepatocytes and HepG2 cells by regulating cyclin-cdk activities. Liver Int. 23: 179-186; 2003. doi:10.1034/j.1600-0676.2003.00829.x.

Arterburn, L. M.; Zurlo, J.; Yager, J. D.; Overton, R. M.; Heifetz, A. H. A morphological study of differentiated hepatocytes in vitro. Hepatology 22: 175-187; 1995.

Bader, A.; Knop, E.; Kern, A.; Boker, K.; Fruhauf, N.; Crome, O.; Esselmann, H.; Pape, C.; Kempka, G.; Sewing, K. F. 3-D coculture of hepatic sinusoidal cells with primary hepatocytesdesign of an organotypical model. Exp. Cell Res. 226: 223-233; 1996. doi:10.1006/excr.1996.0222.

Bertagnolo, V.; Puviani, A. C.; Brogli, M.; Carini, C.; Brugnoli, F.; Colamussi, M. L.; Bellini, G.; Morsiani, E.; Capitani, S. Retinoic acid maintains differentiated cell morphology and functions in long-term cultured porcine hepatocytes: obtaining functional cells for prolonged treatments with bioartificial liver. Int. J. Artif. Organs 26: 498-506; 2003.

Bhatia, S. N.; Balis, U. J.; Yarmush, M. L.; Toner, M. Effect of cellcell interactions in preservation of cellular phenotype: cocultivation of hepatocytes and nonparenchymal cells. Faseb J. 13: 1883-1900; 1999.

Block, G. D.; Locker, J.; Bowen, W. C.; Petersen, B. E.; Katyal, S.; Strom, S. C.; Riley, T.; Howard, T. A.; Michalopoulos, G. K. Population expansion, clonal growth, and specific differentiation patterns in primary cultures of hepatocytes induced by HGF/SF, EGF and TGF alpha in a chemically defined (HGM) medium. $J$. Cell Biol. 132: 1133-1149; 1996. doi:10.1083/jcb.132.6.1133.

Edwards, I. J.; O'Flaherty, J. T. Omega-3 fatty acids and PPARgamma in cancer. PPAR Res 2008: 358052 only still online; 2008.

Elaut, G.; Henkens, T.; Papeleu, P.; Snykers, S.; Vinken, M.; Vanhaecke, T.; Rogiers, V. Molecular mechanisms underlying the dedifferentiation process of isolated hepatocytes and their cultures. Curr. Drug Metab. 7: 629-660; 2006. doi:10.2174/ 138920006778017759.

Enat, R.; Jefferson, D. M.; Ruiz-Opazo, N.; Gatmaitan, Z.; Leinwand, L. A.; Reid, L. M. Hepatocyte proliferation in vitro: its dependence on the use of serum-free hormonally defined medium and substrata of extracellular matrix. Proc. Natl. Acad. Sci. US A 81: 1411-1415; 1984. doi:10.1073/pnas.81.5.1411.

Falasca, L.; Favale, A.; Serafino, A.; Ara, C.; Conti Devirgiliis, L. The effect of retinoic acid on the re-establishment of differentiated hepatocyte phenotype in primary culture. Cell Tissue Res. 293: 337-347; 1998. doi:10.1007/s004410051125.

Falasca, L.; Marcellini, P.; Ara, C.; Rufo, A.; Devirgiliis, L. C. Growth inhibition and induction of specific hepatic phenotype expression by retinoic acid in HEPG2 cells. Anticancer Res. 19: 3283-3292; 1999.
Fields, A. L.; Soprano, D. R.; Soprano, K. J. Retinoids in biological control and cancer. J. Cell Biochem. 102: 886-898; 2007. doi:10.1002/jcb. 21530 .

Iynedjian, P. B.; Marie, S.; Gjinovci, A.; Genin, B.; Deng, S. P.; Buhler, L.; Morel, P.; Mentha, G. Glucokinase and cytosolic phosphoenolpyruvate carboxykinase (GTP) in the human liver. Regulation of gene expression in cultured hepatocytes. J. Clin. Invest. 95: 1966-1973; 1995. doi:10.1172/JCI117880.

Kawaguchi, R.; Yu, J.; Honda, J.; Hu, J.; Whitelegge, J.; Ping, P.; Wiita, P.; Bok, D.; Sun, H. A membrane receptor for retinol binding protein mediates cellular uptake of vitamin A. Science 315: 820-825; 2007. doi:10.1126/science.1136244.

Khetani, S. R.; Chen, A. A.; Ranscht, B.; Bhatia, S. N. T-cadherin modulates hepatocyte functions in vitro. Faseb J. 2211: 3768-3775; 2008.

Khetani, S. R.; Szulgit, G.; Del Rio, J. A.; Barlow, C.; Bhatia, S. N. Exploring interactions between rat hepatocytes and nonparenchymal cells using gene expression profiling. Hepatology 40: 545-554; 2004. doi:10.1002/hep.20351.

Kmiec, Z. Cooperation of liver cells in health and disease. Adv. Anat. Embryol. Cell Biol. 161III-XIII: 1-151; 2001.

Langenbach, R.; Malick, L.; Tompa, A.; Kuszynski, C.; Freed, H.; Huberman, E. Maintenance of adult rat hepatocytes on $\mathrm{C} 3 \mathrm{H} /$ 10T1/2 cells. Cancer Res. 39: 3509-3514; 1979.

Lim, Y. S.; Lee, H. C.; Lee, H. S. Switch of cadherin expression from E- to N-type during the activation of rat hepatic stellate cells. Histochem. Cell. Biol. 127: 149-160; 2007.

Lu, H. F.; Chua, K. N.; Zhang, P. C.; Lim, W. S.; Ramakrishna, S.; Leong, K. W.; Mao, H. Q. Three-dimensional co-culture of rat hepatocyte spheroids and NIH/3T3 fibroblasts enhances hepatocyte functional maintenance. Acta Biomater. 1: 399-410; 2005. doi:10.1016/j.actbio.2005.04.003.

Mitaka, T. The current status of primary hepatocyte culture. Int. J. Exp. Pathol. 79: 393-409; 1998. doi:10.1046/j.13652613.1998.00083.x.

Miura, K.; Nagai, H.; Ueno, Y.; Goto, T.; Mikami, K.; Nakane, K.; Yoneyama, K.; Watanabe, D.; Terada, K.; Sugiyama, T.; Imai, K.; Senoo, H.; Watanabe, S. Epimorphin is involved in differentiation of rat hepatic stem-like cells through cell-cell contact. Biochem. Biophys. Res. Commun. 311: 415-423; 2003. doi:10.1016/j.bbrc.2003.09.225.

Morin, O.; Normand, C. Long-term maintenance of hepatocyte functional activity in co-culture: requirements for sinusoidal endothelial cells and dexamethasone. J. Cell Physiol. 129: 103110; 1986. doi:10.1002/jcp.1041290115.

Moriwaki, H.; Blaner, W. S.; Piantedosi, R.; Goodman, D. S. Effects of dietary retinoid and triglyceride on the lipid composition of rat liver stellate cells and stellate cell lipid droplets. J. Lipid Res. 29: 1523-1534; 1988.

Okamoto, M.; Ishida, Y.; Keogh, A.; Strain, A. Evaluation of the function of primary human hepatocytes co-cultured with the human stellate cell (HSC) line LI90. Int. J. Artif. Organs 21: 353-359; 1998.

Pestel, S.; Schlaf, G.; Gotze, O.; Jungermann, K.; Schieferdecker, H. L. Differences in the involvement of prostanoids from Kupffer cells in the mediation of anaphylatoxin C5a-, zymosan-, and lipopolysaccharide-dependent hepatic glucose output and flow reduction. Lab. Invest. 83: 1733-1741; 2003. doi:10.1097/01. LAB.0000101727.89483.37.

Probst, I.; Beuers, U.; Drabent, B.; Unthan-Fechner, K.; Butikofer, P. The diacylglycerol and protein kinase $\mathrm{C}$ pathways are not involved in insulin signalling in primary rat hepatocytes. Eur. J. Biochem. 270: 4635-4646; 2003. doi:10.1046/j.14321033.2003.03853.x.

Riccalton-Banks, L.; Liew, C.; Bhandari, R.; Fry, J.; Shakesheff, K. Long-term culture of functional liver tissue: three-dimensional coculture of primary hepatocytes and stellate cells. Tissue Eng. 9: 401-410; 2003. doi:10.1089/107632703322066589. 
Ries, K.; Krause, P.; Solsbacher, M.; Schwartz, P.; Unthan-Fechner, K.; Christ, B.; Markus, P. M.; Probst, I. Elevated expression of hormone-regulated rat hepatocyte functions in a new serum-free hepatocyte-stromal cell coculture model. In Vitro Cell Dev. Biol. Anim. 36: 502-512; 2000. doi:10.1290/1071-2690(2000) 036<0502:EEOHRR $>2.0 . \mathrm{CO} ; 2$.

Runge, D.; Runge, D. M.; Jager, D.; Lubecki, K. A.; Beer Stolz, D.; Karathanasis, S.; Kietzmann, T.; Strom, S. C.; Jungermann, K.; Fleig, W. E.; Michalopoulos, G. K. Serum-free, long-term cultures of human hepatocytes: maintenance of cell morphology, transcription factors, and liver-specific functions. Biochem. Biophys. Res. Commun. 269: 46-53; 2000. doi:10.1006/bbrc.2000.2215.

Sato, M.; Suzuki, S.; Senoo, H. Hepatic stellate cells: unique characteristics in cell biology and phenotype. Cell Struct. Funct. 28: 105-112; 2003. doi:10.1247/csf.28.105.

Sauvant, P.; Sapin, V.; Alexandre-Gouabau, M. C.; Dodeman, I.; Delpal, S.; Quadro, L.; Partier, A.; Abergel, A.; Colantuoni, V.; Rock, E.; Azais-Braesco, V. Retinol mobilization from cultured rat hepatic stellate cells does not require retinol binding protein synthesis and secretion. Int. J. Biochem. Cell Biol. 33: 10001012; 2001. doi:10.1016/S1357-2725(01)00066-8.

Schrode, W.; Mecke, D.; Gebhardt, R. Induction of glutamine synthetase in periportal hepatocytes by cocultivation with a liver epithelial cell line. Eur. J. Cell Biol. 53: 35-41; 1990.

Senoo, H. Structure and function of hepatic stellate cells. Med. Electron. Microsc. 37: 3-15; 2004. doi:10.1007/s00795-003-0230-3.

Seubert, W.; Huth, W. On the mechanism of gluconeogenesis and its regulation. II. The mechanism of gluconeogenesis from pyruvate and fumarate. Biochem. Z. 343: 176-191; 1965.

Suematsu, M.; Aiso, S. Professor Toshio Ito: a clairvoyant in pericyte biology. Keio J. Med. 50: 66-71; 2001.

Talamini, M. A.; McCluskey, M. P.; Buchman, T. G.; De Maio, A. Expression of alpha2-macroglobulin by the interaction between hepatocytes and endothelial cells in coculture. Am. J. Physiol. 275: R203-R211; 1998.
Thomas, R. J.; Bhandari, R.; Barrett, D. A.; Bennett, A. J.; Fry, J. R.; Powe, D.; Thomson, B. J.; Shakesheff, K. M. The effect of threedimensional co-culture of hepatocytes and hepatic stellate cells on key hepatocyte functions in vitro. Cells Tissues Organs 181: 67-79; 2005. doi:10.1159/000091096.

Tontonoz, P.; Spiegelman, B. M. Fat and beyond: the diverse biology of PPARgamma. Annu. Rev. Biochem. 77: 289-312; 2008. doi:10.1146/annurev.biochem.77.061307.091829.

Watanabe, S.; Hirose, M.; Wang, X. E.; Ikejima, K.; Oide, H.; Kitamura, T.; Takei, Y.; Miyazaki, A.; Sato, A. A novel hepatic stellate (Ito) cell-derived protein, epimorphin, plays a key role in the late stages of liver regeneration. Biochim. Biopys. Res. Comm. 250: 486-490; 1998. doi:10.1006/ bbrc.1998.9339.

Weiner, F. R.; Blaner, W. S.; Czaja, M. J.; Shah, A.; Geerts, A. Ito cell expression of a nuclear retinoic acid receptor. Hepatology 15: 336-342; 1992. doi:10.1002/hep.1840150226.

Yamada, M.; Blaner, W. S.; Soprano, D. R.; Dixon, J. L.; Kjeldbye, H. M.; Goodman, D. S. Biochemical characteristics of isolated rat liver stellate cells. Hepatology 7: 1224-1229; 1987. doi:10.1002/ hep. 1840070609 .

Yoshino, R.; Miura, K.; Segawa, D.; Hirai, Y.; Goto, T.; Ohshima, S.; Mikami, K.; Yoneyama, K.; Shibuya, T.; Watanabe, D.; Kataoka, E.; Takeuchi, S.; Endoh, A.; Sato, W.; Watanabe, S. Epimorphin expression and stellate cell status in mouse liver injury. Hepatol. Res. 34: 238-249; 2006. doi:10.1016/j. hepres.2005.12.011.

Zinchenko, Y. S.; Culberson, C. R.; Coger, R. N. Contribution of nonparenchymal cells to the performance of micropatterned hepatocytes. Tissue Eng. 12: 2241-2251; 2006a. doi:10.1089/ ten.2006.12.2241.

Zinchenko, Y. S.; Schrum, L. W.; Clemens, M.; Coger, R. N. Hepatocyte and kupffer cells co-cultured on micropatterned surfaces to optimize hepatocyte function. Tissue Eng. 12: 751761; 2006b. doi:10.1089/ten.2006.12.751. 